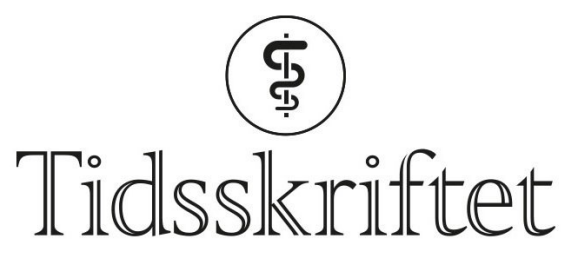

DEN NORSKE LEGEFORENING

\title{
Helter i hvitt?
}

KRONIKK

\section{ESPEN GAMLUND}

Espen Gamlund er professor i filosofi ved Institutt for filosofi og førstesemesterstudier, Universitetet i Bergen.

Forfatteren har fylt ut ICMJE-skjemaet og oppgir ingen interessekonflikter.

\section{KARL ERIK MÜLLER}

Karl Erik Müller er ph.d. og LIS2-lege ved Medisinsk avdeling, Vestre Viken, Drammen sykehus.

Forfatteren har fylt ut ICMJE-skjemaet og oppgir ingen interessekonflikter.

\section{AMALIE C. SOLBERG}

Amalie C. Solberg er lege.

Forfatteren har fylt ut ICMJE-skjemaet og oppgir ingen interessekonflikter.

\section{CARL TOLLEF SOLBERG}

E-post: carl.solberg@uib.no

Carl Tollef Solberg er ph.d., lege, filosof og postdoktor ved Bergen senter for etikk og prioritering (BCEPS), Institutt for global helse og samfunnsmedisin, Universitetet i Bergen.

Forfatteren har fylt ut ICMJE-skjemaet og oppgir ingen interessekonflikter.

Har leger en moralsk plikt til å gi helsehjelp selv om de skulle mangle tilstrekkelig smittevernutstyr under en pandemi? Verken Genève-deklarasjonen, Legeforeningens etiske retningslinjer eller Norges lover gir oss noe presist svar. Vi vil argumentere for at svaret er nei. Leger som yter helsehjelp uten mulighet for adekvat smittevern, gjør mer enn de har plikt til, og det kan ses på som heltemodig.

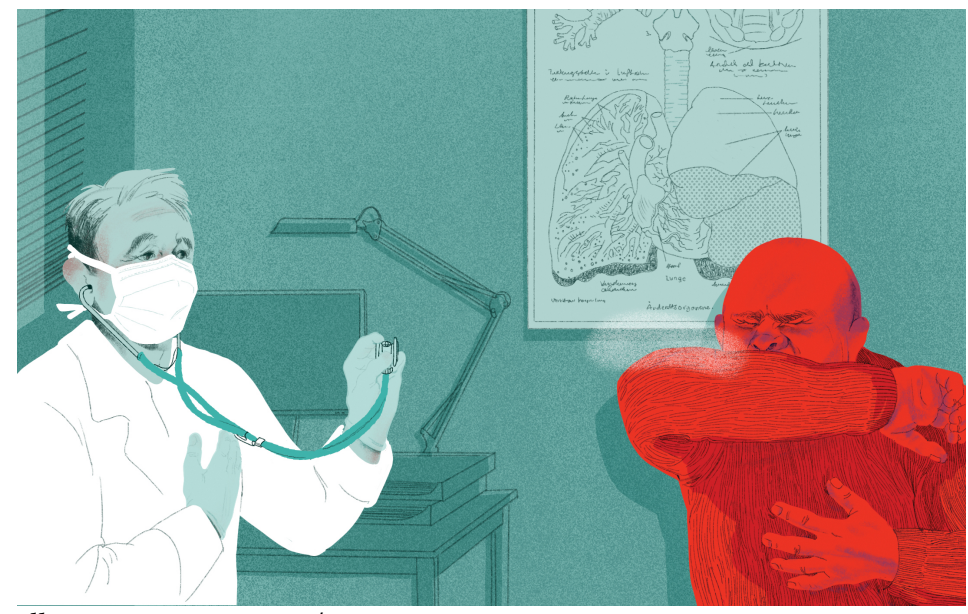

Illustrasjon: Miss Boo / Bente Jørgensen 
Ultimo desember 2019 varslet den kinesiske oftalmologen Li Wenliang om et mulig SARSlignende utbrudd i Wuhan. Han oppfordret sine kollegaer sterkt til å beskytte seg selv. Den 7. februar 2020 døde dr. Wenliang som følge av infeksjon med SARS-CoV-2-viruset, bare 33 år gammel (1). Per 23. september 2020 var det ifølge $\mathrm{WHO}_{31,4}$ millioner bekreftede smittetilfeller og over 967 ooo bekreftede dødsfall som følge av koronapandemien (2). Flere av de døde er leger og andre helsearbeidere $(3,4)$.

Under koronapandemien har mange helsearbeidere vært nødt til å utsette seg for større risiko enn normalt for å diagnostisere og behandle pasienter med covid-19 (5, 6). Normalt har sykehus i høyinntektsland adekvat og tilstrekkelig smittevernsutstyr, men pandemien gjorde det raskt klart at vi ikke befant oss i en normalsituasjon. Leger og andre helsearbeidere har derfor sett seg tvunget til å tilby medisinsk hjelp til smittede personer, uten tilstrekkelig mulighet for selvbeskyttelse $(5,7)$.

\section{Hva kreves av legene?}

Flere offentlige retningslinjer og etiske kodekser har til hensikt å klargjøre hva som kan kreves av leger. I den hippokratiske eden er legens ivaretagelse av egen helse ikke nevnt (8). Først i den nyere revisjonen (2017) av Genève-deklarasjonen omtales legens plikt til å ta vare på seg selv (9, vår oversettelse): "Jeg vil ivareta min egen helse, min velferd og mine evner, for å kunne gi omsorg og behandling av beste standard.» Denne begrunnelsen er i hovedsak instrumentell (en syk lege er en dårlig lege). I Legeforeningens etiske retningslinjer heter det at «en lege skal verne menneskehetens helse», og videre at «en lege bør ta vare på egen helse og søke hjelp dersom denne svikter» (10, 11). Begrunnelsen for det siste har forblitt uuttalt, og kan enten forklares instrumentelt, med en begrunnelse om iboende verdi (legen er en person som er verdifull i seg selv, på lik linje med andre mennesker) eller som en kombinasjon av de to.

Genève-deklarasjonen innledes for øvrig med følgende ord: «Som et medlem av den medisinske profesjonen [...] lover jeg høytidelig å vie mitt liv til menneskehetens tjeneste» (9, vår oversettelse). Et springende punkt her er hva vi bør legge i det å vie sitt liv til noe. En mild tolkning innebærer at legen bør bruke store deler av tiden sin på legegjerningen, mens en mer radikal tolkning innebærer at legen bør være villig til å ofre noe av sin egen helse. I alle tilfeller kan deklarasjonen forstås dit hen at legegjerningen har en selvoppofrende side, hvilket taler i favør av et positivt svar på vårt hovedspørsmål: Leger bør forventes å tilby helsehjelp selv om det innebærer en viss risiko for deres egen helse.

Til forskjell fra de etiske kodeksene fokuserer lovverket på legen som arbeidstager. I arbeidsmiljøloven heter det at «ved planlegging og utforming av arbeidet skal det legges vekt på å forebygge skader og sykdommer», og videre at «nødvendige hjelpemidler skal stilles til arbeidstakers disposisjon» (12). I helsepersonelloven fremgår det at «en virksomhet som yter helse- og omsorgstjenester, skal organiseres slik at helsepersonellet blir i stand til å overholde sine lovpålagte plikter» (13). Og Legeforeningen skriver i en uttalelse at helsepersonell ikke kan pålegges oppgaver som setter eget liv i fare (10).

Lovens og Legeforeningens uttalelser pålegger kanskje ikke leger å sette sitt eget liv i fare. Men ovennevnte lovverk og etiske kodekser gir oss ikke tilstrekkelig svar på hvordan vi skal balansere det «å vie sitt liv til menneskehetens tjeneste» med det å «ta vare på egen helse». Denne tvetydigheten fører oss inn i et moralsk vanskelig farvann. Antagelig fins det $\mathrm{i}$ samfunnet og i legestanden selv en stilltiende forventning om at leger strekker seg langt, og ofte lenger enn det loven krever.

La oss utdype dette nærmere med to tenkte eksempler. Først: Forestill deg at du kommer til en trafikkulykke. Første bud er å sikre skadestedet og egen sikkerhet før du skal varsle og deretter sette i gang livreddende behandling. Normen ved trafikkulykker er at egensikkerheten kommer først. Forestill deg deretter at du som lege tilkalles til en pasient med alvorlig pustebesvær og feber. Du får beskjed om at det er tomt for smittevernutstyr. Det forventes at du likevel skal hjelpe pasienten, med en risiko for å smitte deg selv og 
andre. Det siste eksemplet er ikke utenkelig ved en pandemi. Bør vi akseptere den siste formen for risiko, men ikke den første?

Det er en moralsk forskjell mellom det å bli påført risiko og det å påta seg risiko

Selvsagt er det forskjell på trafikkulykker og smittesituasjoner. Ved trafikkulykker er årsaksforholdet mellom hendelsen og skaden åpenbart, mens det i smittetilfeller er komplekst (hvor blant annet kroppens immunsystem og pasientens komorbiditet spiller inn). Videre opptrer personskader i trafikkulykker som regel umiddelbart. I smittetilfeller kan det derimot ta lang tid før skaden tar sin mest alvorlige form. Dessuten: Der trafikkulykken har et noenlunde forutsigbart skadeomfang, er covid-19 mer uforutsigbar. Når det er sagt - om vi hadde antatt at legen løp like stor risiko for helseskade i begge de tenkte eksemplene, hvorfor skulle vi da tilsynelatende være mer opptatt av sikkerheten i trafikkulykken enn i smittesituasjonen?

Det er en moralsk forskjell mellom det å bli påført risiko på den ene siden og det å påta seg risiko på den annen side. I klinisk sammenheng kan det imidlertid være vanskelig å skille mellom de to. De fleste handlinger leger utfører på jobb, er gjerne både frivillige og samtidig underlagt stilltiende forventninger eller krav og en viss frykt for sanksjoner om jobben ikke blir skikkelig utført.

\section{Helten}

La oss si at det virkelig er slik at det finnes stilltiende forventninger eller krav om at leger bør kunne risikere egen helse for å hjelpe smittede under koronapandemien. Er det å kreve for mye av dem? Dette spørsmålet griper inn i en dypere moralfilosofisk diskusjon av hva moralen krever, en diskusjon det er betydelig uenighet rundt. Noen mener moralen krever at vi mennesker bør være villige til å ofre noe av vår egen velferd for å hjelpe vanskeligstilte (14). Andre hevder moralen kun krever at vi ikke utsetter andre for skade eller risiko for skade. Likevel er de fleste enige om at vi ikke kan kreve at personer ofrer liv og helse for å hjelpe andre, uansett hvor hjelpetrengende de er. Det betyr at slike selvoppofrende handlinger kan normalt sett ikke være plikter. De er snarere overplikter, handlinger som overskrider det vi har plikt til. En helt i den forstand vi her snakker om, er nettopp en som gjør noe overpliktig. Det kan riktignok være beundringsverdig om vi utsetter oss selv for risiko for å hjelpe andre, men det er ikke moralsk galt om vi unnlater å gjøre det.

Et nærliggende eksempel på en slik overplikt er en lege som melder seg frivillig til å yte medisinsk hjelp i et katastrofeområde. Vi kan ikke kreve at leger yter slik hjelp, men det er flott og beundringsverdig dersom de gjør det. Filosofen James Opie Urmson hevder at den som utfører slike heltemodige handlinger, selv vil oppleve at hun er bundet av en plikt til å utføre dem, selv om disse handlingene ikke egentlig er plikter (15). Trolig er det derfor en asymmetri mellom hvordan legen opplever at hun bør yte medisinsk hjelp til tross for at det innebærer personlig risiko, og det faktum at hjelpen ikke er moralsk påkrevet. Leger som ikke reiser til et katastrofeområde, er ikke klanderverdige, men de som likevel gjør det, fortjener ros og beundring.

Selvoppofrende handlinger kan normalt sett ikke være plikter. De er snarere overplikter

Urmson legger til grunn at helter blir sett opp til og beundret. De gjør på forskjellige vis mer enn hva som kreves av dem (15). Dette bildet blir mer komplisert når vi snakker om hva som kreves og forventes av profesjonsutøvere, slik som leger og brannmenn. Da flyene traff tvillingtårnene i New York 11. september 2001, måtte brannmannskapet utføre ekstraordinært arbeid for å slokke brann og redde liv. Brannmannskapene løp stor personlig risiko ved å løpe inn i tvillingtårnene for å redde mennesker ut, og mange av dem mistet livet (16). De ble beundret for sin heltemodige innsats. På den annen side ville de antagelig ha blitt møtt med kritikk dersom de ikke hadde utvist heltemot, fordi de da simpelthen ikke ville ha gjort jobben sin skikkelig. Konklusjonen blir derfor at det forventes, og kanskje også kreves, at man som brannkonstabel løper en egenrisiko i 
utførelsen av arbeidet (noen ganger en betydelig egenrisiko). Samtidig er det man gjør, heltemodig.

Hva så med leger? I mange land har helsepersonell de siste månedene måttet gjennomføre arbeidet sitt til tross for manglende beskyttelsesutstyr (5). På linje med brannkonstabelen forventes og kanskje kreves det av legen at hun løper en egenrisiko i utførelsen av legegjerningen. Hvis hun nekter å gjøre dette, risikerer hun å bli møtt med kritikk, men dersom hun gjør det, gjør hun noe heltemodig. Det kan høres paradoksalt ut, men skyldes de særskilte normene som tilhører bestemte profesjoner. Det anses å tilhøre legeyrket å strekke seg langt for å hjelpe andre, noen ganger så langt at man løper egenrisiko. Det både forventes og noen ganger kreves at man gjør dette. Samtidig blir slikt heltemot regnet som beundringsverdig i allmennmoralsk sammenheng. Det er fordi vi verken forventer eller krever av folk at de løper en tilsvarende egenrisiko for å hjelpe andre.

\section{Konklusjon}

Vi har argumentert for at norske leger ikke har moralsk plikt til å yte helsehjelp i smittesituasjoner hvor de mangler adekvat smittevernutstyr. Selv om lovverket, retningslinjer og etiske kodekser ikke forventer at leger skal sette sitt eget liv i fare, er det likevel mange som både forventer og krever av leger at de yter helsehjelp under tidvis stor smitterisiko. Dermed er det grunn til å tro at en del leger sannsynligvis strekker seg lenger enn det de har en moralsk plikt til i møte med covid-19 og andre smittsomme sykdommer. Noen av disse handlingene er heltemodige.

\section{LITTERATUR:}

1. Green A. Li Wenliang. Lancet 2020; 395: 682. [CrossRef]

2. World Health Organization. Coronavirus disease (COVID-19) pandemic.

https://www.who.int/emergencies/diseases/novel-coronavirus-2019 Lest 31.9.2020.

3. Ing EB, Xu QA, Salimi A et al. Physician deaths from corona virus (COVID-19) disease. Occup Med (Lond) 2020; 70:370-4. [PubMed][CrossRef]

4. Gouda D, Singh PM, Gouda P et al. The demography of deaths in healthcare workers - an overview of 1004 reported COVID-19 deaths. American Board of Family Medicine 2020.

https://www.jabfm.org/sites/default/files/COVID_20-0248.pdf Lest 31.9.2020.

5. Godlee F. Protect our healthcare workers: Indian government vows to protect healthcare workers from violence amid rising cases. BMJ 2020;369: m1324. [PubMed][CrossRef]

6. Chersich MF, Gray G, Fairlie L et al. COVID-19 in Africa: care and protection for frontline healthcare workers. Global Health 2020; 16: 46. [PubMed][CrossRef]

7. Emanuel EJ, Persad G, Upshur R et al. Fair allocation of scarce medical resources in the time of Covid-19. N Engl J Med 2020; 382: 2049-55. [PubMed][CrossRef]

8. Holck P, Skålevåg SA. Den hippokratiske ed. https://sml.snl.no/hippokratiske_ed Lest 21.6.202o.

9. Parsa-Parsi RW. The revised declaration of Geneva: A modern-day physician's pledge. JAMA 2017; 318: 1971-2. [PubMed][CrossRef]

10. Den norske legeforening. Øyeblikkelig hjelp. Hva forventes?

https://www.legeforeningen.no/jus-og-arbeidsliv/rettigheter-og-plikter-for-lege-og-pasient/oyeblikkeli g-hjelp/\#19983 Lest 28.6.2020.

11. Den norske legeforening. Etiske regler for leger.

https://www.legeforeningen.no/om-oss/Styrende-dokumenter/legeforeningens-lover-og-andre-organi satoriske-regler/etiske-regler-for-leger/ Lest 21.6.2020.

12. LOV-2005-06-17-62. Lov om arbeidsmiljø, arbeidstid og stillingsvern.

https://lovdata.no/dokument/NL/lov/2005-06-17-62 Lest 28.6.2020.

13. LOV-1999-07-02-64. Lov om helsepersonell. https://lovdata.no/dokument/NL/lov/1999-07-02-64 Lest 
28.6.2020.

14. Singer P. The life you can save: How to do your part to end world poverty. New York, NY: Random House, 2010.

15. Urmson J. Saints and heroes. I: Essays in moral philosophy. Seattle: University of Washington Press, 1958.

16. Kiger P. How 9/11 Became the deadliest day in history for U.S. firefighters.

https://www.history.com/news/9-11-world-trade-center-firefighters Lest 28.6.2020.

Publisert: 26. oktober 2020. Tidsskr Nor Legeforen. DOI: 10.4045/tidsskr.20.0702

Mottatt 3.9.2020, godkjent 28.9.2020.

(C) Tidsskrift for Den norske legeforening 2020. Lastet ned fra tidsskriftet.no 